\title{
AS LÁGRIMAS DE MARIA MADALENA: MAR DE AMOR E DOR
}

\section{GEISE KELLY TEIXEIRA DA SILVA}

Universidade de Porto geisekelly21@hotmail.com

RESUMO: O presente trabalho apresenta uma leitura do canto X do Memorial dos Milagres de Cristo, poema épico do século XVII escrito pela religiosa cisterciense Soror Maria de Mesquita Pimentel. Pretende-se, com esta análise, demonstrar como alguns dos processos retórico-poéticos mobilizados pela autora no referido canto - cujo núcleo narrativo é a conversão de Maria Madalena- em articulação com os afetos que suscita, assumem uma função retórica de persuasão que apela ao pathos do leitor no sentido de chamar sua atenção para o comportamento penitente de Maria Madalena enquanto modelo a ser seguido por todos os crentes, especialmente pela mulher cristã, que deveria libertar-se dos laços mundanos para converter-se em um modelo exemplar de santidade em consonância com as coordenadas propostas pelo Concílio de Trento.

PALAVRAS-CHAVE: Maria Madalena; epopeia religiosa; Soror Maria de Mesquita Pimentel; literatura conventual feminina; Memorial dos Milagres de Cristo. 


\section{THE TEARS OF MARY MAGDALENE: sea of love and pain}

ABSTRACT: This essay presents a reading of canto X of Memorial dos Milagres de Cristo, epic poem written by Cistercian religious Sister Maria de Mesquita Pimentel in the 17 th century. This analysis seeks to demonstrate how some of the rhetorical-poetic processes mobilized by the author in that canto - whose narrative core is the conversion of Mary Magdalene-, in conjunction with the affections that raises, take a rhetoric of persuasion function that calls for pathos of the reader in order to draw your attention to the penitent behavior of Mary Magdalene as a role model to be followed by all believers, especially the christian woman who should free themselves from worldly bonds to be converted into an exemplary model of holiness, in line with the proposals coordinated by the Council of Trent.

KEY WORDS: Mary Magdalene; religious epic; Sister Maria de Mesquita Pimentel; Conventual women's literature; Memorial dos Milagres de Cristo.

figura de Maria Madalena foi um dos leitmotiv mais explorados pela - Igreja Católica desde a Idade Média até finais do século XVIII. A par de todas as variantes míticas e biográficas ${ }^{1}$ que enriqueceram o seu nome através dos séculos, sua figura esteve quase sempre associada ao pecado

${ }^{1}$ Sabe-se que a figura de Maria Madalena como hoje a conhecemos é resultado de um longo e complexo processo de "aglutinações". Sua identidade ainda hoje não é consensual, embora a tradição tenha condensado em uma só personagem, sobretudo após a Homilia XXXIII de Gregório Magno, aspectos das três figuras femininas referidas nos quatro evangelhos canônicos: a Maria de Betânia, irmã de Marta e Lázaro; original e à luxúria, uma condensação de toda a imperfeição do sexo feminino que durante muito tempo contribuiu para sustentar a misoginia tradicional e serviu de base para a elaboração de um dos mais emblemáticos modelos morais do Cristianismo.

$\mathrm{O}$ arquétipo de "pecadora penitente" forjado em torno de sua imagem prolifera na hagiografia e se difunde através da arte e da literatura devota. Como uma segunda Eva, a figura de Maria Madalena passará a ser situada como contraponto frente ao ideal de perfeição da Virgem Maria, assinalando com o seu exemplo de pecadora e penitente a possibilidade de que também estas mulheres, marginalizadas e depreciadas pela sociedade, poderiam alcançar o perdão e a santidade. Mais do que isso, sua figura irá representar um modelo de comportamento penitente a ser seguido e imitado pela mulher cristã, seja ela jovem, casada ou viúva. Não é por acaso que o gesto mais eloquente da santa é a sua postura de joelhos, uma posição que representa humilhação e inferioridade diante de Cristo, constituindo um ritual que terá lugar particularmente na comunidade monástica e cada vez mais enraizada nos hábitos religiosos femininos.

Se na arte religiosa dos séculos XVI e XVII a representação de Maria Madalena prolifera tanto como "mirrófora" quanto penitente, no campo literário, seja sacro ou profano, notar-se-á uma visível preponderância das lágrimas numa clara sintonia com a sensibilidade religiosa da época, que viveu intensamente a consciência do pecado e a necessidade do arrependimento e conversão. Com efeito, vários pregadores e tratadistas evocaram Madalena e suas lágrimas para estimular a meditação dos fiéis, principalmente as mulheres. Suas lágrimas também virão a constituir um tópico bastante atrativo aos olhos de eclesiásticos, poetas e dramaturgos que, inspirados tanto nos evangelhos quanto na Legenda Áurea, de Jacopo da Voragine, e no seu traslado português —o Flos Sanctorum-, transformam-na em uma personagem carregada de simbolismo.

$\mathrm{Na}$ Península Ibérica vamos nos deparar com uma larga fortuna literária acerca da vida desta peccatrix, o que demonstra a enorme popu-

a mulher inominada de São Lucas, e a Maria de Magdalo, de quem foram expulsos sete demônios.

UNED. REI, 5 (2017), pp. 9-28

ISSN 2340-9029 
laridade alcançada por esta santa no sul da Europa. Sua representação em Portugal $^{2}$, nesse mesmo período, não se distancia muito dos contornos apresentados na Idade Média (Barbas, 1997: 179). Sem perder os traços arquetípicos de pecadora, Maria Madalena será transformada em um modelo de "santidade heroica" de central importância no contexto da Contrarreforma, convertendo-se em um símbolo autêntico do arrependimento e penitência para edificação dos fiéis.

É de surpreender, contudo, a escassa repercussão de uma das figuras mais representativas da piedade barroca na literatura conventual feminina em Portugal no período moderno, ainda mais se considerarmos a função modeladora assumida por grande parte dessa literatura (Morujão, 2013: 479). Isabel Morujão refere que apesar de Maria Madalena ter sido objeto de tratamento poético em quase todas as poetisas, não se verifica uma grande expansão ou qualquer assinalável recorrência nos exemplares de que temos conhecimento ${ }^{4}$.

2 Para o caso de Portugal, cita-se alguns exemplos como: Conversam e lágrimas da gloriosa Sancta Maria Magdalena e obras espirituais, de Diogo Mendes Quintela (Quintela, 1615); as elegias de Jorge da Silva e de Francisco de Sá de Menezes publicadas com a obra Tractado em que se contem a Paixam de Christo, segundo o Texto dos Euangelistas muy deuotamente moralizada \& outra doctrina muito deuota \& proueitosa q[ue] mostra os proueitos de se juntar hu[m] a alma cõ Xpo \& duas elegias à bem auenturada Madalegna (SILVA, 1589); a Elegia IX de António Ferreira (Ferreira 1598); e o Soneto XXI, de Sá de Miranda, publicado em Poesias de Francisco de Sá de Miranda (Miranda, 1989: 81-82). A propósito desses e de outros autores, ver o artigo "Maria Madalena: lágrimas, amor e culpa", de Luís de Sá Fardilha (1995) e a tese de doutoramento de Maria Helena Barbas (1997) intitulada Imagens e Sombras de Santo Maria Madalena na Literatura e Arte Portuguesa.

${ }^{3}$ Duby; Perrot, 1994: 198

${ }^{4}$ Isabel Morujão cita como exemplos de incursões do heroico na literatura conventual feminina os poemas escritos por D. Helena da Silva, com a sua ordenação da Vida de Nossa Senhora, escrita a partir dos versos de Virgílio, e o Poema a la Pasión de Cristo; também Ave Peregrina e Primaz do deserto, de Soror Maria do Céu; e A Cristo baixando o limbo e Jacob e Raquel, de Soror Madalena da Glória. Para saber mais, consultar Morujão, 2013: 140-182.
Contudo, é no Memorial dos Milagres de Cristo ${ }^{5}$, um poema épico do século XVII ${ }^{6}$ escrito por Soror Maria de Mesquita Pimentel7, que encontraremos alguns traços marcantes da presença dessa santa. Um dos aspectos que irrompe com o que há de mais inesperado neste poema é o protagonismo que a religiosa cisterciense atribui à Maria Madalena, já que, nenhum outro texto conhecido da literatura conventual feminina confere a essa personagem tamanho relevo. Neste Memorial dos Milagres, entretanto, Soror Mesquita Pimentel dedica todo o canto X à "pecadora arrependida", que é amplamente focalizada ao longo de 93 estrofes escritas em oitava rima, recuperando a tradição dramática que se construiu em torno dessa figura feminina.

Da mesma forma que os diversos sermões e textos hagiográficos exploraram a imagem de Maria Madalena no esplendor de sua beleza antes do arrependimento e depois a verter rios de lágrimas aos pés de Cristo, Soror Mesquita Pimentel também explora as duas facetas de sua personagem,

${ }^{5} \mathrm{O}$ Memorial dos Milagres de Cristo, que até pouco tempo permaneceu inédito, foi editado pela primeira vez em 2015 (Cf. Morujão/ Conde/ Morujão, 2015). Além deste poema épico, estruturado em versos decassilábicos escritos em oitava rima, Soror Maria de Mesquita Pimentel escreveu também o Memorial da Infância de Cristo e Memorial da Paixão de Cristo, obras que, juntamente com a primeira, constituem uma trilogia que narra a vida de Cristo desde o seu nascimento até a sua morte e ressurreição. Desses três poemas, apenas o Memorial da infância foi publicado em 1639. O Memorial dos Milagres, como já referido, foi editado em 2015, e o Memorial da Paixão ainda continua inédito, embora a sua edição já esteja a ser ultimada por uma equipe de investigação coordenada pela Professora Isabel Morujão.

${ }^{6}$ Embora o manuscrito não esteja datado, toma-se como parâmetro o século XVII como período de produção tendo em conta que o Memorial da Infância foi editado em 1639. Contudo, suspeita-se que o Memorial da Paixão tenha sido escrito ainda em finais do século XVI, já que foi o primeiro dos três poemas a serem escritos pela autora, conforme explicitado nos paratextos de censura e ainda prólogo do leitor do Memorial da Infância, no qual Soror Pimentel declara: "Os que o seu Memorial/ Da Paixão solenizastes,/ Recebei com gosto igual/ Este, pois os bens fundaste/ Na Infância celestial". (Pimentel, 1639: fl. inumerado)

${ }^{7}$ No que se refere à vida dessa autora, sabe-se basicamente que ela foi uma religiosa professa no mosteiro de São Bento de Cástris, em Évora, nascida em 1586, para além de algumas informações sobre sua origem e filiação, conforme pontua Antónia Fialho Conde na edição do Memorial dos Milagres de Cristo (Morujão/ Conde/ Morujão, 2015: 50-62).

UNED. REI, 5 (2017), pp. 9-28

ISSN 2340-9029 
esboçando a imagem de uma mulher atraída pelo luxo e vaidade para, em seguida, transformá-la em um modelo de amor e penitência para edificação de seu público leitor, convocando, para isso, "os elementos persuasivos mais eloquentes da época” (Morujão, 2013: 483).

É acerca desse "pendor persuasivo" que pretendo debruçar-me ao longo deste trabalho, buscando, sobretudo, sublinhar os processos estilísticos que vão sendo gradualmente erigidos no canto épico de Soror Mesquita Pimentel para promover a captação de seu destinatário à maneira do consagrado conceito horaciano do ut pictura poesis. Ocupar-me-ei, por agora, apenas em demonstrar como alguns dos processos retórico- poéticos por ela mobilizados, em articulação com os afetos que suscita, contribuem para comover e persuadir o leitor no sentido de chamar sua atenção para o comportamento penitente de Maria Madalena enquanto modelo a ser seguido, em especial pelo público feminino a que se destina, visando atingir objetivos que vão de encontro às coordenadas propostas pelo Concílio de Trento.

A partir desta análise, pretende-se também dar visibilidade a um tipo de produção que abarca, em vários sentidos, a expressão da marginalidade feminina em Portugal na Idade Moderna; marginalização no que diz respeito à condição de mulher e de religiosa da autora; à posição também marginal de sua personagem enquanto pecadora; e também ao caráter "periférico" que a escrita conventual feminina, por seu estatuto de menoridade, ainda hoje apresenta no contexto dos estudos históricos e literários. Relegada durante muito tempo ao esquecimento, essa obra chega aos nossos dias como um eco das muitas vozes femininas que ao longo dos séculos passados foram silenciadas pela historiografia literária portuguesa, ilustrando um quadro da escrita feminina que se processou a margem do cânone literário e sob o peso de uma sociedade enraizada nos valores patriarcais.

Um dos primeiros aspectos que salta à vista do leitor no canto $\mathrm{X}$ do Memorial dos Milagres de Cristo é a presença de uma série de elementos que se aproximam das convenções retórico-poéticas do período em que foi constituído, sendo patente o aproveitamento e atualização de alguns dos códigos estético-literários da altura, como metáforas minerais e natu- rais na construção do retrato feminino; a mitologia clássica greco-latina; e figuras de linguagem (metáfora, hipérboles, antíteses, paradoxos). Conforme veremos mais adiante, a força do ut pictura poesis e os vários elementos retórico-poéticos que se disseminam ao longo da narrativa, em articulação com os afetos que se expressam na "linguagem das lágrimas", resultam como estratégias eficazes para mobilizar no leitor emoções com vista à comoção e persuasão.

Antes de aprofundar estes aspectos, é preciso ter em conta não apenas as normas que moldavam a construção do texto conventual feminino, mas também as influências que algumas das coordenadas mais evidentes do pensamento estético-literário da altura exerceram sobre a escrita de Soror Mesquita Pimentel, o que nos remete para o panorama literário de Seiscentos, século atravessado pela filosofia estética do Barroco e ao longo do qual assistimos à proliferação de obras voltadas para a conservação e difusão da doutrina católica. Forjado pela conjuntura da época, este $M e$ morial, assim como muitas outras obras emanadas da clausura feminina, configura-se como uma forma de literatura edificante e formadora "cuja função era a de tornar próxima e real para os cristãos a existência divina, exercitando a adesão dos leitores pela via emotiva e pelo agenciamento de uma retórica adequada” (Morujão, 2013: 145).

Dada a funcionalidade que a sua obra assume no âmbito dos conventos femininos, é o tipo de leitor visado que irá condicionar o estilo adotado por Soror Mesquita Pimentel. O que está em jogo no método composicional de seu canto épico não é a beleza das palavras enquanto expressão de engenho, mas a valoração da res diante do verbum, ou seja, o que interessa é a exaltação da vida da santa Maria Madalena enquanto símbolo de amor e penitência a ser valorizado pelos cristãos. Para conduzir o leitor nessa direção, a autora lança mão de artifícios próprios do discurso epidítico (laudatório), de modo a garantir a produção de um efeito emotivo capaz de suscitar a reflexão.

À semelhança dos muitos textos de piedade e sermões produzidos naquela época, no canto X de seu Memorial dos Milagres ${ }^{8}$ a poetisa tam-

${ }^{8}$ À título de análise, utilizamos aqui a recente edição do Memorial dos Milagres 
bém irá explorar o motivo das lágrimas para comover o leitor e, por essa via, colocá-lo diante da problemática do arrependimento, conversão e penitência. Na medida em que desenvolve os afetos na elocução de seu poema, a poetisa mescla em sua linguagem alguns artifícios retórico-poéticos, recorrendo ao uso de metáforas, hipérboles e analogias para amplificar a projeção dos afetos ao passo que louva a superioridade da beleza da santa Maria Madalena e a grandeza de suas virtudes. Essa correlação, como oportunamente veremos, favorece a recepção da mensagem que pretende veicular. Primeiro, porque os afetos que o poema suscita envolvem o leitor numa teia emotiva, causando-lhe comoção; e segundo, porque a amplificação, enquanto artifício retórico, atinge a disposição do público pela admiração que as imagens despertam, tornando-se particularmente um dispositivo de persuasão na medida em que se assenta na sedução dos sentidos.

$\mathrm{O}$ argumento que antecede o canto antecipa o assunto de que se pretende dar notícia: a vida e conversão de Maria Madalena. Ao longo das 93 estrofes que o constituem, a "pecadora arrependida" aparece mergulhada num mar de amor e dor, inundando todo o canto com as suas lágrimas; lágrimas de contrição motivadas pela dor de seus pecados e pelo sentimento de culpa e arrependimento, mas que também expressam o grande amor que sente por Cristo; lágrimas que a narradora toma para si, fazendo-nos caminhar lado a lado com a pecadora arrependida e sentir com ela as suas dores.

É com "voz de choro e de alegria" que a narradora começa a contar a história de sua heroína. O ponto de partida é Jerusalém, lugar onde viviam seus pais, Siro e Eucária, senhores ilustres e "opulentos nas riquezas". Após informar o leitor acerca da origem e filiação nobre de Madalena, a autora passa ao lugar comum da humildade: "Não é de tosca mão tão alta empresa/ por ser digna de engenho sobre-humano/ que se afoga no mar de tal beleza" (Morujão/ Conde/ Morujão, 2015: canto X, estr. 6a , 375), descrevendo com pormenores as características físicas da pecadora, representando-a no auge de sua beleza e formosura inigualáveis.

(Morujão/ Conde/ Morujão, 2015), de modo que todos os excertos citados ao longo do texto serão, a partir de agora, referenciados apenas com a identificação do canto em análise (canto $\mathrm{X}$ ), seguidos da estrofe e sua respectiva página.
Mais adiante é referido o primeiro encontro de Maria Madalena com Jesus, que estava a pregar no Templo. Com suas palavras e vista penetrante, Cristo repreendia suas maldades de tal modo que Maria chorava e cobria-se com seu manto. Envergonhada e com o peito trespassado de dor, a pecadora foge em direção a sua casa e, ao chegar a seus aposentos, "o freio solta ao choro reprimido" e "com o coração rasgado de tormento/ despiu o seu riquíssimo vestido/ e ficou sem as joias preciosas/ mais ricas com as lágrimas fermosas" (Morujão/ Conde/ Morujão, 2015: canto X, estr. 41 a , 387). Banhada em lágrimas de arrependimento, Maria Madalena passa a recriminar a vaidade e o "falso amor", inaugurando um monólogo que se prolonga por cinco estrofes, condenando a si mesma por ter preferido as "imagens falsas e fingidas" aos "verdadeiros bens". O peso de suas culpas é tão grande que deseja antes a própria morte do que ter cometido algum pecado.

Logo após, a narradora regressa para afirmar o estado de conversão de Maria Madalena, agora, já desvestida dos adornos do mundo. Depois de ter com o mundo "contas rematadas", a pecadora convertida toma um vaso de precioso unguento "e com humilde traje logo parte/ para ir buscar de Cristo a melhor parte” (Morujão/ Conde/ Morujão, 2015: canto $\mathrm{X}$, estr. 51 a , 390). Durante o percurso, Madalena derrama suas lágrimas por todo o caminho por onde passa. Os pés, que antes a conduziam velozmente por caminhos perigosos, parecem-lhe, naquele momento, demasiado vagarosos, tamanho é o seu desejo de estar na companhia de Cristo. Interpela, então, a seus pés: "Por que não is com asas, pés, voando/ por que vá mais depressa a Deus chegando?” (Morujão/ Conde/ Morujão, 2015: canto X, estr. 55a, 391 ), desejando que estes tivessem asas para que voando fizessem-na chegar mais depressa à fonte de sua glória.

Segue-se, então, o episódio em casa de Simão, o fariseu. Aqui, a autora recria quase textualmente a cena narrada em Lucas 7, 36-50. Entrando em casa do fariseu Simão, Maria avista Jesus sentado à mesa e tamanha é a sua dor e culpa que "não ousa ver-lhe a face esclarecida/ mas encolhida vai, por detrás passa” (Morujão/ Conde/ Morujão, 2015: canto X, estr. 58a, 392). Daí em diante, é narrado o momento em que Maria Madalena lava os pés de Jesus com suas lágrimas e seca-os com seus cabelos: e "depois que 
com seu doce choro grave/ lavou a Cristo os pés divino ofício", "os cabelos soltou, laço suave/ e por lhe dar de amor mais claro indício/ com este ouro espalhado lhos limpava/ e infinitos ósculos lhe dava" (Morujão/ Conde/ Morujão, 2015: canto X, estr. 65a , 395). Em seguida, derrama sobre os seus pés o alabastro de perfume que traz consigo, "metida num incêndio tão ardente/ não fala uma palavra do que sente" (Morujão/ Conde/ Morujão, 2015: canto X, estr. 67a , 395). O fariseu Simão, que estava a observar a atitude de Maria Madalena perante Cristo e conhecia a má fama que ela tinha, "logo dentro em si diz murmurando" (Morujão/ Conde/ Morujão, 2015: canto X, estr. 70a , 396) que se Jesus fosse realmente um profeta, ele certamente saberia que aquela mulher que lhe lavara e beijara os pés era uma pecadora da cidade e, por isso, "era razão que logo a despedisse/ e que estar a seus pés não consentisse” (Morujão/ Conde/ Morujão, 2015: canto $\mathrm{X}$, estr. 71a , 397).

A narrativa prossegue recriando o quadro da parábola dos dois devedores, presente em Lucas 7, 41-42, no momento em que Jesus dialoga com Simão, comparando a sua (ausência de) atitude com as ações de Maria Madalena, que terá todos os seus pecados perdoados por amar a Cristo com tanto excesso. Madalena parte, então, enriquecida, levando a situação narrativa ao desfecho com os comensais "olhando-se uns aos outros admirados" e a perguntar quem é este homem que "tem em si cifrados/ os poderes de Deus alto e celeste” (Morujão/ Conde/ Morujão, 2015: canto X, estr. 91'a 403).

A leitura que este canto oferece permite-nos observar um particular dramatismo, que se concentra, sobretudo, no momento em que Maria Madalena arrepende-se de seus pecados e na cena do lavatório dos pés. A presença redundante e hiperbólica das lágrimas, constantemente explorada pela poetisa, intensifica a expressão da dor sentida pela pecadora, emprestando à narrativa uma eloquência ímpar que apela ao pathos do leitor devoto e provoca nele comoção pelo suscitar dos afetos. Maria Madalena não apenas chora, mas "corrente de lágrimas lançava" (Morujão/ Conde/ Morujão, 2015: canto X, estr. 60a , 393) e "cento de fio em fio lhe corriam" (Morujão/ Conde/ Morujão, 2015: canto X, estr. 61ª, 393). O monólogo ferido e prolongado da pecadora não deixa de demonstrar uma clara in- tenção da poetisa em captar a adesão de seu destinatário, exercendo sobre ele uma ação transformadora na medida em que o faz meditar sobre a dor e sofrimento da personagem, identificando-se com ela e projetando nela a si próprio.

Neste ponto, é interessante observar que o que antes motiva a conversão da pecadora não é influência do amor que lhe havia inspirado Cristo, mas sim o temor de vir a irritar a Deus e ser condenada a penas eternas. É evidente a intenção de despertar no leitor cristão uma adesão emocional baseada no medo, pois a autora apresenta diante dele a ira de Deus e o inferno a arder em fogo ${ }^{9}$, transformando o monólogo de Maria Madalena e a dramatização de seu conflito interior em uma exortação, já que na medida em que sua personagem recrimina a si própria, explicando a sua reprovável conduta, seu discurso estabelece com o leitor devoto, em particular a mulher cristã, uma espécie de admoestação, funcionando como exemplo e aconselhando todos os fiéis que se enredam em caminhos semelhantes a envergonhar-se de seus pecados, chorar suas culpas e a converter-se, assim como fez Maria Madalena. É de notar que, este tipo de construção, baseada no medo, é algo característico das pautas religiosas impostas pelo movimento contrarreformista, uma vez que não corresponde com a imagem evangélica da pecadora que lavou os pés de Jesus, em quem o impulso afetivo resulta mais importante que o temor (Sánchez Ortega, 1995).

Igualmente interessante é o ritmo demorado que a poetisa confere a esta cena, construindo uma espécie de gradação pelo intensificar do pranto. Algo semelhante pode ser também observado no momento anterior à unção. Desde a entrada de Maria Madalena na casa do fariseu até a unção propriamente dita, a sequência dos acontecimentos nos é narrada com impressionante lentidão, prolongando-se por nove estrofes. Contudo, importa destacar que esse alargamento não se dá a nível da progressão narrativa, mas na expressão dos gestos e sentimentos de Madalena.

9 Vejam-se os seguintes versos: "Olha e vê de uma parte Deus irado/ E de outra o fogo arder no inferno/ O piedoso céu está cerrado/ E vê-se assi metida neste aperto" (Morujão/ Conde/ Morujão, 2015: canto X, estr. 43, 387).

UNED. REI, 5 (2017), pp. 9-28

ISSN 2340-9029 
Aos pés do bom Jesus chorando estava

Humilde, vergonhosa e mui confusa,

Tal corrente de lágrimas lançava

Que parecia Bíblis ou Aretusa.

E quão forçosamente que chorava

Movida da divina infusa,

Porque vestia lágrimas tão belas

Que parece que o Céu chora as estrelas!

(Morujão/ Conde/ Morujão, 2015: canto X, estrofe 60a , 393)

O vaso de alabastro já derrama

Nos pés que com seu pranto tem lavados

Nos quais se prende, enreda, enlaça, inflama

Despois que com doçura os tem beijados.

Nunca cessa de obrar quem muito ama

E em todos estes termos delicados

Metida num incêndio tão ardente

Não fala uma palavra do que sente.

(Morujão/ Conde/ Morujão, 2015: canto X, estrofe 67a, 395 )

Veja-se que o que mais avulta nestes versos não são propriamente as ações de Maria, mas a intensidade e riqueza expressiva de seus sentimentos. Se nos relatos evangélicos esta cena é narrada com uma certa economia, Soror Mesquita Pimentel, pelo contrário, confere uma maior amplitude aos gestos de sua personagem, cujas lágrimas emprestam um realismo particular e dramático à narrativa. Mas, não são apenas as lágrimas de Maria Madalena que permeiam o texto. A narradora/poetisa também chora a dor de sua personagem, mas é um choro que ao mesmo tempo expressa alegria por saber que ela, "porque soube chorar”, encontrou consolo e perdão em Cristo. Não só isso: sua escrita constitui uma prática de exercício espiritual através da qual a própria autora trabalha o autoaperfeiçoamento e o exercício ascético tão preconizado pela cultura monástica, cuja doutrina baseava-se no desapego do mundo e no desejo de Deus. Por esse motivo, é possível identificar os próprios sentimentos da autora a permear o texto; sentimentos de amor, devoção e comoção que se misturam às lágrimas de sua personagem e adensam o dramatismo de sua história.
Para além dos movimentos afetivos que se observam em toda a narrativa, sublinhe-se a dimensão visual deste poema, percebida principalmente na descrição física de Maria Madalena antes de sua conversão e na sequência narrativa de suas ações, como numa espécie de exercício espiritual inaciano ${ }^{10}$. Tal qual um pintor, a narradora "pinta" diante de nossos olhos um quadro da "santa pecadora" a partir da enumeração de suas particularidades físicas, imprimindo uma certa vitalidade que salta à vista do leitor. Maria Madalena aparece desenhada com "olhos de diamante" e longas "madeixas de ouro";
A fronte tinha cândida e serena
Sobrancelha arqueada e assaz escura
Para mais realçar da Madalena
A cor do rostro igual, a neve pura;
Suas formosas faces de açucena
Em que a púrpura e neve mais se apura
O nariz que as divide era aquilino
Em que pôs natureza o pincel fino.
(Morujão/ Conde/ Morujão, 2015: canto X, estr. 9a , 376)
Sua boca que é qual rubim partido
Com perfilo sutil alionado
Admirando, descobre dividido
Rico nácar de pérolas guardado;
E não tinha valor menos subido
Em seu rostro perfeito e acabado
A barba de cristal linda, engraçada
Por esmalte no meio mui rosada.
(Morujão/ Conde/ Morujão, 2015: canto X, estr. 10a, 377)

10 Em seus Exercícios Espirituais, Santo Inácio propõe métodos de examinar a consciência, meditar, contemplar e orar vocal e mentalmente a partir do exercício da prática constante da "composição vendo o lugar". No primeiro preâmbulo, da primeira semana, Santo Inácio sugere: "Aqui é de notar que, na contemplação ou meditação visível, como, por exemplo, contemplar a Cristo, Nosso Senhor, o qual é visível, a composição será ver, com a vista da imaginação, o lugar material onde se acha o que quero contemplar. Digo lugar material, como, por exemplo, um templo ou montanha onde se acha Jesus Cristo ou Nossa Senhora, conforme o que quero contemplar" (Loiola, 2012: 41-42).

UNED. REI, 5 (2017), pp. 9-28

ISSN 2340-9029 
A descrição da santa em seu estado de pecadora segue ainda por outras estrofes: a garganta "de azuis e roxas veias se jaspeia" (Morujão/ Conde/ Morujão, 2015: canto X, estr. 12a , 377), “as mãos são de marfim e pura neve" (Morujão/ Conde/ Morujão, 2015: canto X, estr. 13a, 377), esboçando um retrato que segue a mesma verticalidade da composição clássica do retrato feminino, cujo enfoque voltava-se para as partes nobres da mulher, como assim o fizeram inúmeros poetas dos quais temos conhecimento através do Cancioneiro Geral de Garcia de Resende. Desse modo, a poetisa fornece ao leitor um material pictórico que encontra expressão nos códigos tradicionais da representação feminina, utilizando-se de elementos naturais e preciosos (ouro, diamante, esmeralda, rubi, pérola e cristal) e de qualidades (branca, neve, pura) para metaforizar a raridade da beleza e pureza da santa. Como se demonstrasse o ut pictura poesis, Soror Mesquita Pimentel "pinta" a sua personagem de modo semelhante aos inúmeros retratos pintados pela poesia da altura. Tal como aparece em Góngora e Camões, "cabelos de ouro", "olhos de diamante”, "pele branca” e "boca de rubi” são metáforas que remetem a uma larga fortuna da tradição petrarquista e, ainda que não desviem sua obra da tônica pedagógica cristã, imputam-lhe uma certa fruição estética.

Não obstante, na medida em que retoma metáforas consagradas pela poética de seu tempo, Soror Mesquita Pimentel não descura da lei do decorum horaciano, adequando os seus versos ao tema e à função de sua obra ao passo que reveste a sua personagem de uma indumentária cristã que se expressa por meio de metáforas colhidas nos campos semânticos do luminoso (raios, luz, sol, estrelas, fogo, aurora). Nota-se, desse modo, uma transladação do motivo poético da beleza feminina para o plano da religiosidade, configurando uma forma de divinização de sua personagem e da matéria narrada em atenção aos códigos que orientavam e moldavam a escrita religiosa.

É a partir daí que passaremos a observar de forma mais depurada e significativa os vários recursos retórico-poéticos que incidem por trás da composição plástica do retrato da santa e de alguns quadros narrativos. Configurando um método da amplificação normalmente usado nos gêneros epidíticos, a descriptio ${ }^{11}$ adquire uma dimensão pragmática importante para qualquer discurso que tem por fim o movere, justamente em função do efeito perlocutório que essa composição exerce sobre o leitor. Ao representar Maria Madalena desse modo, a autora faz com que sua imagem seja projetada diante dos olhos do leitor pela força do ponere ante oculo, envolvendo-o em uma teia de sentidos que se processa por meio de um exercício de imaginação. Os adjetivos que realçam a beleza da santa Maria Madalena, além de reforçar a sua singularidade e raridade, têm a finalidade de louvar e engrandecer aquela que mais soube amar a Cristo, cabendo, pois, à poetisa amplificar tais virtudes, de modo a assinalar a sua superioridade. Para tanto, Soror Pimentel recorre a metáforas, hipérboles e analogias para distinguir a sua personagem, de modo a provocar no leitor admiração pela beleza que suscita, o que por sua vez faz deslocar a imagem do que é representado para um plano onde, segundo Sócrates, "parece mais admiravelmente maravilhoso do que antes” (apud Alves, 2001: 13).

A contemplação de alguns quadros narrativos também contribui para a ilação dessa função suasória. Os relatos que envolvem a personagem Maria Madalena abundam em pormenores que iluminam os seus gestos com uma força plástica admirável, fazendo-nos acompanhar cada um de seus passos como se pudéssemos vislumbrar os acontecimentos com o mesmo olhar da narradora. Será interessante enumerar alguns dos sintagmas verbais que descrevem plasticamente a sua ação: "Na casa de Simão vai já entrando" (Morujão/ Conde/ Morujão, 2015: canto X, estr. 57a, 392); "Mas encolhida vai, por detrás passa" (Morujão/ Conde/ Morujão, 2015: canto X, estr. 58 a 392); “Aos pés do bom Jesus chorando estava” (Morujão/ Conde/ Morujão, 2015: canto X, estr. 60ª 393); “o vaso de alabastro já derrama” (Morujão/ Conde/ Morujão, 2015: canto X, estr. 67a , 395). A articulação discursiva destas cenas produz imagens que envolvem o leitor

${ }^{11}$ A descriptio, conforme prescreve Quintiliano no livro VIII de sua Instituição Oratória, é um procedimento elocutivo utilizado na descrição de pessoas, lugares, ações, caráter, etc., e serve como técnica de amplificação do discurso. Utilizando-se de metáforas, comparações e epítetos, a descriptio visa atingir a clareza do discurso e a eficácia visual a partir da representação das coisas como se fossem quadros, de modo a imprimir-lhes uma vivacidade capaz de fazer "ver diante dos olhos" e, por essa via, comover e persuadir o leitor/ouvinte/espectador mais facilmente.

UNED. REI, 5 (2017), pp. 9-28

ISSN 2340-9029 
na narrativa e apela à interiorização de uma presença. A vivacidade da descriptio de que fala Quintiliano, provoca a impressão de presença do referente quase como se este pudesse ser colocado "ante os olhos". Atrelada aos afetos e aos caracteres que lhes correspondem, a imagem representada permite, desse modo, que o leitor construa na alma aquilo que não é possível captar pelos sentidos. Por conseguinte, a plasticidade de algumas imagens oferecidas pela poetisa, em articulação com os afetos que suscita, acaba envolvendo o leitor na matéria narrada para melhor comover os ânimos e persuadir

Pode-se dizer ainda que o uso de tais adjetivos e metáforas serve para por em perspectiva a imagem da pecadora antes e depois de sua conversão, produzindo um efeito de contrastes que indicia a orientação retórica subjacente no discurso narrativo de Soror Mesquita Pimentel. Na estrofe $23^{a}$, percebemos de forma mais explícita essa intencionalidade:

Estrela celestial, se aqui me atrevo

A vos pintar com tinta negra e escura,

É porque firme intento na alma levo

De mostrar cedo a vossa fermosura;

As sombras como é certo e entender devo

Fazem resplandecer mais a pintura,

Tais nossas culpas são, e a sombra delas

Vos fará mais fulgente que as estrelas.

(Morujão/ Conde/ Morujão, 2015: canto X, estr. 23a , 381)

Veja-se que os adjetivos "negra” e "escura” produzem um efeito contrastivo em relação ao discurso elogioso e "iluminado" com que a personagem é descrita. De acordo com Sánchez Ortega, essa duplicidade de imagens "puede provocar em el espectador, gracias a este contraste, uma impresión mucho más profunda” (Sánchez Ortega, 1995: 256) na medida em que emparelha elementos antitéticos para promover uma reflexão sobre o mundo das vaidades. Do ponto de vista discursivo, trata-se de uma estratégia que pretende colocar o leitor devoto diante de dois polos distintos: o pecado e o arrependimento. É por isso que a narrativa se constrói dividida em duas partes: na primeira, Maria Madalena aparece revestida de rica pedraria, ressaltando-se o seu estado de pecadora; já na segunda, após o arrependimento e conversão, a santa é retratada sem nenhum adorno. A representação dos traços físicos que ressaltam a sua beleza corresponde à imagem de uma mulher entregue às vaidades do mundo e serve de pretexto para a sua posterior "desfiguração", provocando no leitor um maior efeito suasório no sentido de conscientizá-lo sobre a fugacidade da beleza e os perigos que o "falso amor" oferece. Vale a pena retomar aqui mais alguns versos:

Esta sua sem par rara beleza

A muita liberdade e poucos anos

Ser muito conquistada e ter riqueza

Causas assaz forçosas pera danos

Lhe foi ocasião para que presa

Ficasse com os laços dos enganos

E que tanto ao profano amor se desse

Que o divino amor de Deus perdesse.

(Morujão/ Conde/ Morujão, 2015: canto X, estr. 18ª, 379)

É a presença proeminente de Maria Madalena, ainda em seu estado de pecadora, que irá imprimir no leitor o sentimento de contrição; "rara beleza", "liberdade", "poucos anos" e "riqueza" são combinações que constituem um recorrente clichê dos sermões penitenciais e chama a atenção para os perigos de gozar da beleza e formosura, pois a beleza pode ser tão perigosa para a mulher que a possui quanto para o homem que a contempla. Na medida em que "encena" ao leitor os costumes de Maria Madalena na sua fase de pecadora, Soror Mesquita Pimentel esboça a personalidade de uma figura feminina distante do universo moral e social valorizado pelo Cristianismo, bem como do esquema normativo o qual deveria seguir a mulher cristã. $\mathrm{O}$ monólogo ferido e prolongado de Madalena antes da conversão expressa o conflito interior de uma mulher dividida entre o "amor sacro" e o "amor profano" que também constituiu um dilema para as mulheres do Antigo Regime (Sánchez Ortega, 1995: 279) e que, neste canto em particular, deixa entrever a sobrevivência do estereótipo feminino da debilidade da mulher no discurso da religiosa de Évora. Depois de ilustrar a vida dissipada de sua personagem, a autora passa a relatar o processo de conversão que irá transformá-la de pecadora 
em fiel seguidora de Cristo, constituindo um autêntico modelo de arrependimento e penitência.

Se no início de seu canto épico a poetisa dá a entender que contará apenas a história da vida e conversão de Maria Madalena, o desenrolar de sua narrativa revela outra intenção. Mais do que apenas louvar a santa, Soror Mesquita Pimentel demonstra buscar exercer também uma influência transformadora sobre o seu público leitor. A adequação de todos os processos retóricos por ela mobilizados demonstra uma preocupação em captar a adesão do destinatário, na medida em que intensifica a projeção dos afetos e explora alguns dos lugares-comuns de textos consagrados na altura e que aparecem recolhidos nas inúmeras narrativas sobre a conversão de Maria Madalena. A contemplação dos quadros evocados constitui uma súmula da vida ascética tal como sintetizada pelos ensinamentos de $\mathrm{S}$. Paulo e pretende conduzir os fieis à prática da perfeição cristã, principalmente as mulheres, que deveriam procurar aperfeiçoar suas próprias virtudes para que fossem exemplos por excelência da mulher cristã perfeita.

Embora que, do ponto de vista temático, o texto da autora seja apenas mais um entre os vários que a sua época produziu em tempos de Contrarreforma, não deixa de ser interessante observar os influxos estilísticos que se manifestam através de um prolongado desenvolvimento poético dos textos bíblicos. Por esses aspectos particulares é que considerei a relação entre retórica clássica e cristã uma perspectiva de leitura pertinente na abordagem deste texto de Soror Mesquita Pimentel. É certo que seu processo de tessitura esteve orientado pelo conjunto de regras que regiam a escrita feminina, sobretudo dentro dos conventos, devendo-se, por isso, evitar excessos condenáveis. No entanto, não se pode afirmar categoricamente que a autora tenha escrito a sua obra sem qualquer preocupação formal, ainda que esta não tenha sido a sua principal intenção. O conhecimento dos artifícios e procedimentos retóricos que a poetisa demonstra ter serve não apenas para atestar que a sua obra não esteve desvinculada das estruturas retóricas de pensamento ou que tampouco se processaram em um contexto isolado. Antes, demonstra que, naquela altura, contrariando a ideia da inferioridade intelectual feminina presente no discurso patriarcal, era possível, sim, que uma mulher fosse capaz de escrever obras de reconhecido valor estético, a exemplo de Soror Maria de Mesquita Pimentel, uma religiosa que, na sua dupla condição feminina e cristã, soube conjugar um código linguístico fortemente retórico dentro de um gênero tão rico e pouco aventurado por mulheres.

Recibido: $11 / 4 / 2017$

Aceptado: 10/6/2017

\section{Referências Bibliográficas}

Alves, Hélio J. S. (2001), Camões, Corte-Real e o Sistema da Epopeia Quinhentista. Coimbra: Por Ordem da Universidade.

Aristóteles (2013), Poética, trad., pref. Eudoro de Souza, Lisboa: Relógio d'água, $4^{\text {a }}$ ed.

Barbas, Helena Maria D. F. M (1997), Imagens e Sombras de Santa Maria Madalena na Literatura e Arte Portuguesa, Lisboa: Universidade de Nova Lisboa (Tese de Doutoramento).

Bíblia Sagrada (1959), Tradução da vulgata e anotada pelo Padre Matos Soares, São Paulo: Edições Paulinas, $3^{\mathrm{a}} \mathrm{ed}$.

Castro, Aníbal Pinto de (1973), Retórica e teorização literária em Portugal. Do humanismo ao neoclassicismo, Coimbra: Centro de Estudos Românicos.

Dias, José Sebastião da Silva (1960), Correntes do Sentimento Religioso em Portugal (Séculos XVI a XVIII), Coimbra: Universidade de Coimbra.

Duby, Georges y Michelle Perrot (1994), História das Mulheres do Renascimento à Idade Moderna, Porto: Edições Afrontamento, vol. 3.

Fardilha, Luís de Sá (1995), "Maria Madalena: lágrimas, amor e culpa”, Via Spiritus, 2, pp. 7-36.

Ferreira, António (1598), Poemas Lusitanos, Lisboa: por Pedro Crasbeeck, a custa de Estevão Lopez. 
Inácio de Loiola, Santo (2012), Exercícios espirituais, Braga: Livraria Apostolado da Imprensa, $4 .^{\text {a }}$ ed.

Miranda, Francisco de Sá de (1989), Poesias de Francisco de Sá de Miranda, ed. Carolina Michaëlis de Vasconcelos, reprodução em fac-símile do exemplar com data de 1885 da Biblioteca Nacional, Lisboa: Imprensa Nacional-Casa da Moeda.

Morujão, Isabel (2013), Por trás da grade. Poesia conventual feminina em Portugal (Séculos XVI - XVIII), Lisboa: Imprensa Nacional-Casa da Moeda.

--- coord., Antônia Fialho Conde y Maria do Rosário Morujão (2015), Em treze Cantos: epopeia feminina em recinto monástico. O Memorial dos Milagres de Cristo de Maria de Mesquita Pimentel, Braga: CITCEM/CIDEHUS/ CHSC.

Pimentel, Maria de Mesquita (1639), Memorial da Infância de Cristo e Triunfo do Divino Amor, Lisboa: Miguel Rodrigues.

Pimentel, Maria de Mesquita, Memorial da Paixão. Texto manuscrito da Biblioteca Pública de Évora, Cod. 406, Fundo Manizola (em vias de publicação).

Quintela, Diogo Mendes (1615), Conversam e lágrimas da gloriosa Sancta Maria Magdalena e obras espirituais, Lisboa: por Vicente Alvarez.

Quintiliano, M. Fábio (1836), Instituições Oratórias, Paris: impressão de Bourgogne et Martinet.

Resende, Garcia de (1973), Cancioneiro Geral. Nova edição, introdução e notas de Andrée Crabbé Rocha, Lisboa: Centro do Livro Brasileiro, 5 vol.

Sánchez Ortega, María Helena (1995), Pecadoras de verano arrepentidas en invierno. Madrid: Alianza Editorial.

Silva, Jorge da (1589), Tractado em que se contem a Paixam de Christo, segundo o Texto dos Euangelistas muy deuotamente moralizada \& outra doctrina muito deuota \& proueitosa q[ue] mostra os proueitos de se juntar hu[m]a alma cõ Xpo \& duas elegias à bem auenturada Madalegna, Évora: em casa de Martim de Burgos. 